\title{
MAJOR ACTIONS FOR RESEARCH, MANAGEMENT, AND ADOPTION OF PREVENTIVE MEASURES ON SARS-COV-2 IN SEVERE ACUTE RESPIRATORY SYNDROME: A SYSTEMATIC REVIEW
}

\author{
Dr. Idiberto Jose Zotarelli Filho, MSc, Ph.D ${ }^{1}$ \\ ${ }^{1}$ Affiliation not available
}

August 12, 2020

\begin{abstract}
Introduction: In March 2020, the new coronavirus (COVID-19) spread throughout the world, causing respiratory disease and deaths, especially in risk groups such as the elderly, pregnant women, immunocompromised people, and others. The World Health Organization (WHO; WHO, English) declared, on January 30, 2020, that the outbreak of the disease caused by COVID-19 constitutes a Public Health Emergency of international importance. 6,287,771 cases of COVID-19 (93,246 new compared to the previous day) and 379,941 deaths (3,621 new compared to the previous day) were confirmed worldwide by June 3, 2020. In the Region of the Americas, 1,036,155 people who were infected with the new coronavirus recovered, according to data from June 3, 2020. In Brazil, on January 22, 2020, the Center for Emergency Operations in Public Health for COVID-19 has activated, a strategy provided for in the National Response Plan to Public Health Emergencies of the Ministry of Health $(\mathrm{MH})$. Objective: To present, using a systematic review, the main considerations about the existing actions for notification, registration, investigation, management, and adoption of preventive measures on SARS-CoV-2 in Severe Acute Respiratory Syndrome (SARS). Methods: The present study followed a systematic review model. After literary search criteria using the MeSH terms, a total of 58 clinical studies were compared and submitted to eligibility analysis and, after that, 26 studies were selected, following the rules of PRISMA. The search strategy was carried out in the databases PubMed, Embase, Ovid and Cochrane Library, Web Of Science, ScienceDirect Journals (Elsevier), Scopus (Elsevier), OneFile. Main findings and Conclusion: It is recommended that patients diagnosed with SARS be hospitalized and that the cases identified with the symptoms of severity are admitted to an intensive care bed. These symptoms are persistent hemodynamic instability (blood pressure that did not respond to volume replacement $(30 \mathrm{~mL} / \mathrm{kg}$ in the first 3 hours), indicating the use of vasoactive amine, signs, and symptoms of respiratory failure, including hypoxemia ( $\mathrm{PaO} 2$ below $60 \mathrm{mmHg})$ in need supplementation of oxygen to maintain arterial oxygen saturation above $90 \%$, evolution to other organic disorders, such as acute renal failure and neurological dysfunction. It was defined that the clinical criteria for hospital discharge should take into account the improvement of the clinical picture, the absence of tachydyspnea and hypoxia, the absence of O2 supplementation for at least 24 hours, hemodynamic stability, good oral acceptance and absence of fever. Prophylactic use of antibiotics has not recommended, but use should be considered suspect of associated bacterial infection.
\end{abstract}

Keywords: COVID-19. SARS-CoV-2. Severe Acute Respiratory Syndrome. Acute Respiratory Distress Syndrome. Prevention.

Maria Luiza Raduan Meinberg², João Marcelo Raduan Meinberg ${ }^{4}$, João Pedro Raduan Meinberg², Isabela Daher Anbar ${ }^{2}$, João Pedro Daher Anbar ${ }^{2}$, Thiago Melo Ignácio dos Santos ${ }^{3}$, Antonio Carlos Meinberg ${ }^{1}$, Toufic Anbar Neto ${ }^{2}$, Denise Daher Anbar², Idiberto José Zotarelli Filho ${ }^{2,5}$

1. School of Medicine of São José do Rio Preto, Famerp - Discipline of Anesthesiology, São José do Rio Preto/SP, Brazil. 
2. Faceres - Medical School of São José do Rio Preto/SP, Brazil.

3. União Das Faculdades Dos Grandes Lagos (Unilago) Medical School, São José do Rio Preto/SP, Brazil.

4. Faculty of Health Sciences of Barretos-FACISB, Barretos/SP, Brazil.

5. Zotarelli-Filho Scientific Work, São José do Rio Preto/SP, Brazil.

\section{INTRODUCTION}

In the context of epidemics and pandemics, in November 2019, an outbreak of respiratory disease caused by the new coronavirus (SARS-CoV-2), was detected in the city of Wuhan, China [1]. In March 2020, the new coronavirus (COVID-19) spread throughout the world causing respiratory disease and deaths especially in risk groups such as the elderly pregnant women, immunocompromised people, and others [1].

The World Health Organization (WHO) declared, on January 30, 2020, that the disease outbreak caused by COVID-19 constitutes a Public Health The emergency of International Importance - the highest level of alert in the Organization, as provided for in the Regulations International Health. On March 11, 2020, COVID-19 has characterized by WHO as a pandemic [2].

About 6,287,771 cases of COVID-19 (93,246 new about the previous day) and 379,941 deaths (3,621 new concerning the previous day) were confirmed worldwide by June 3, 2020 [3]. In the Region of the Americas, 1,036,155 people who were infected with the new coronavirus recovered, according to data from June 3, 2020. The Pan American Health Organization (PAHO) and WHO is providing technical support to Brazil and other countries, in the preparation and response to the COVID-19 outbreak [4,5].

In Brazil, on January 22, 2020, the Public Health Emergency Operations Center for COVID-19 was activated, a strategy provided for in the National Public Health Emergency Response Plan of the Ministry of Health (MS). Thus, the Ministry of Health established a structured document based on existing actions for notification, registration, investigation, management, and adoption of preventive measures, in analogy to the accumulated knowledge about SARS-CoV-2 and the Influenza Treatment Protocol: 2017 of the MS [6].

The recommendations are also guided by the Covid-19 Expert Consensus for Clinical Management, held on March 10 and 11, 2020, at the headquarters of the Pan American Health Organization / World Health Organization (PAHO / WHO ) in Brasilia, when national and international experts were gathered for discussion and deepening on the subject [8-10].

In this context, Severe Acute Respiratory Syndrome (SARS) (Severe Acute Respiratory Syndrome - SARS) is a severe acute respiratory disease caused by SARS-CoV. SARS is much more drastic than other coronavirus infections [11]. SARS is an influenza-like illness that occasionally causes severe progressive respiratory failure. SARS-CoV was first detected in Guangdong, China, in November 2002 and subsequently spread to more than 30 countries [12]. SARS-CoV is transmitted from person to person by close personal contact. It believed to transmitted more readily by respiratory droplets produced when an infected person coughs or sneezes. The diagnosis of SARS is clinical, and treatment is supportive [13].

Therefore, this study presented through a systematic review the considerations about the actions for notification, registration, investigation, management, and adoption of preventive measures on SARS-CoV-2 in Severe Acute Respiratory Syndrome (SARS).

\section{METHODS}

\section{Study Design}

The present study followed a systematic review model. After literary search criteria using the MeSH Terms that were cited in the item below on "Search strategies", a total of 58 clinical studies were compared that were submitted to the eligibility analysis and, after that, 26 studies were selected (official documents do Brazil, WHO and scientific articles), following the rules of systematic review - PRISMA (Transparent reporting of systematic reviews and meta-analyzes-https: //www.prisma-statement.org/). 


\section{Search Strategy and Information Sources}

The search strategy was carried out in the databases PubMed, Embase, Ovid and Cochrane Library, Web Of Science, ScienceDirect Journals (Elsevier), Scopus (Elsevier), OneFile (Gale) followed the following steps: search by MeSH Terms: COVID -19. SARS-CoV-2. Severe Acute Respiratory Syndrome. Acute Respiratory Distress Syndrome. Prevention, and use of "and" Booleans between mesh terms and "or" among historical findings.

\section{DEVELOPMENT AND DISCUSSION}

\section{Supportive early therapy and monitoring - SARS}

In the context of SARS, it is necessary to administer supplemental oxygen therapy immediately to patients with SARS and difficulty breathing, hypoxemia, or shock with a SpO2 target> 94\% [14]. In adults with signs of emergency (obstruction or shortness of breath, severe respiratory distress, central cyanosis, shock, coma, or seizures), they must receive airway management and oxygen therapy during resuscitation to achieve $\mathrm{SpO} 2$ [?] $94 \%$ [. It is necessary to start oxygen therapy at $5 \mathrm{~L} / \mathrm{min}$ and assess flow rates to reach the $\mathrm{SpO} 2$ target [?] $93 \%$ during resuscitation, or use a face mask with a reservoir bag $(10-15 \mathrm{~L} / \mathrm{min})$ if the patient is in a healthy state critical [14].

After patient stabilization, the target is $\mathrm{SpO} 2>90 \%$ in adults (without pregnancy) and [?] $92 \%-95 \%$ in pregnant patients. In children with emergency signs (obstruction or shortness of breath, severe respiratory distress, central cyanosis, shock, coma, or seizures) they must receive airway management and oxygen therapy during resuscitation to achieve $\mathrm{SpO} 2$ [?] 94\%, otherwise, the goal is $\mathrm{SpO} 2$ [?] 90\%. The use of a nasal cannula is preferable in young children, as they can be better tolerated [15].

Still, it has indicated to use a conservative treatment of fluids in patients with SARS when there is no evidence of shock [16]. Patients with SARS should be treated cautiously with intravenous fluids, as aggressive fluid resuscitation can worsen oxygenation, especially in environments where the availability of mechanical ventilation is limited. This applies to the care of children and adults. It has also indicated to administer antibiotics within an hour of the initial assessment of patients with sepsis, to collect cultures within an hour ideally before starting the antibiotic and descale based on the microbiological result or clinical judgment $[17,18]$.

Also, it was indicated not to routinely administer systemic corticosteroids for the treatment of viral pneumonia or SARS outside clinical trials, except for other reasons. It is necessary to closely monitor patients with SARS for signs of clinical complications such as respiratory failure and rapidly progressing sepsis and apply supportive interventions immediately [19].

Laboratory tests of hematology and biochemistry and ECG should be performed on admission and as clinically indicated to monitor complications, such as acute liver injury, acute kidney injury, acute cardiac injury, or shock. The application of timely, effective, and safe supportive therapies is the mainstay of therapy for patients who develop severe manifestations of COVID-19 [20]. In pregnant patients, after their resuscitation and stabilization, it is necessary to analyze the fetus. It is a differential to understand the patient's comorbidities for individualized care and prognosis. Thus, Table 1 below presents the major clinical syndromes associated with SARS-CoV-2 infection [1].

Table 1. Clinical syndromes associated with SARS-CoV-2 infection [1].

Mild disease

Pneumonia without complications

Severe pneumonia

Acute respiratory distress syndrome (ARDS)

Sepsis

Septic shock
Picture compatible with upper airway infection, without signs of dehydratio

Adult infection of the lower respiratory tract without signs of severity. A ch Adolescent or adult: lower respiratory tract infection with any of the followi Onset or worsening of respiratory symptoms, up to one week after the onset Systemic inflammatory response syndrome with organ dysfunction in the pr Sepsis accompanied by hypotension [mean arterial pressure (MAP) $<65 \mathrm{~mm}$ 


\section{Source: World Health Organization, June 2020, adapted.}

* Acronyms: ARI, acute respiratory infection; BP, blood pressure; bpm, beats/minute; CPAP, continuous positive airway pressure; $\mathrm{FiO} 2$, a fraction of inspired oxygen; MAP, mean arterial pressure; NIV, non-invasive ventilation; OI, oxygenation index; OIU, oxygenation index using $\mathrm{SpO} 2$; $\mathrm{PaO} 2$, partial pressure of oxygen; Peep, positive end-expiratory pressure; SBP, systolic blood pressure; SD, standard deviation; SIRS, systemic inflammatory response syndrome; SAOF, sequential assessment of organ failure; SpO2, oxygen saturation.

\section{Treatment of hypoxemic respiratory failure and SARS}

Recognition of severe hypoxemic respiratory failure occurs when a patient with respiratory distress has failed standard oxygen therapy, requiring advanced oxygen/ventilation support. If these patients need O2 via a nasal catheter greater than 5 liters/minute to sustain SpO2>93\% and/or have a respiratory rate $>28$ ripm or $\mathrm{CO} 2$ retention $(\mathrm{PaCO} 2>50 \mathrm{mmHg}$ and/or $\mathrm{pH}<7.25)$ they should be intubated and mechanically ventilated immediately. Thus, mechanical ventilation should be instituted early in patients with persistent hypoxemic respiratory failure (despite oxygen therapy), respecting appropriate precautionary measures [21]. However, the National Health Surveillance Agency (Anvisa), through Technical Note 4/2020, contraindicates the use of non-invasive mechanical ventilation (NIV) and high-flow nasal catheter (HFNC) [6].

The procedure with endotracheal intubation is necessary if the patient does not respond to oxygen therapy. Patients with SARS, especially young children or people who are obese or pregnant, can quickly desaturate during intubation, requiring pre-oxygenation with an inspired fraction of oxygen (FiO2) at 100\% for 5 minutes, using a facial mask with reservoir bag. Fast-sequence intubation is appropriate after an airway assessment that shows no signs of difficult intubation [22].

The patient submitted to protective invasive mechanical ventilation may be ventilated in volume or controlled pressure mode (VCV or PCV) with a tidal volume equal to $6 \mathrm{~mL} / \mathrm{kg}$ of predicted weight and plateau pressure less than $30 \mathrm{cmH} 2 \mathrm{O}$, with distention pressure or driving pressure (= Plateau pressure minus PEEP) less than $15 \mathrm{cmH} 2 \mathrm{O}$ [7]. It is also necessary to adjust the smallest enough PEEP to maintain SpO2 between 90-95\%, with $\mathrm{FiO} 2<60 \%$ (use ARDSNet's PEEP/FIO2 table for low PEEP (LIGHT SARS). It was found that the use of higher PEEP proved to be causing pulmonary hyperinflation and worsening of the evolution of part of the patients with COVID-19 [7].

In this context, placing patients with SARS in a prone position can improve oxygenation, but patient safety must be guaranteed. In cases of $\mathrm{PaO} 2$ / FIO2 less than 150, with adequate PEEP according to the $\mathrm{PEEP} / \mathrm{FIO} 2$ table, it is suggested to use protective ventilation by placing the patient in a prone position for at least 16 hours. To perform the rotation and to maintain the patient in a prone position, adequate sedoanalgesia should be provided and, if necessary, curarization. The patient can remain supine if, after being "unresponsive", he remains with $\mathrm{PaO} 2$ / FIO2 > 150. Otherwise, one can consider putting the patient back in a prone position [7].

In addition, it is necessary to adopt a conservative fluid management strategy for patients with SARS without tissue hypoperfusion. Prevent the patient from disconnecting from the ventilator, which can result in loss of Peep and atelectasis. It is also necessary to use in-line catheters for suctioning the airways and clamping the endotracheal tube when it is necessary to disconnect (for example, transferring to a transport ventilator or changing the HME filter) [7].

\section{Complication Prevention, Airway Management, and Non-Invasive Ventilation}

In critically ill patients who require care at the ICU level, non-invasive ventilation (NIV), mechanical ventilation, or extracorporeal life support is considered if necessary [23]. The development of SARS and respiratory decompensation plays a central role in the pathogenesis of COVID-19. In this sense, the principles of treatment are listed as hemodynamic management, with vasopressor support, nutritional support, blood glucose control, prompt assessment and treatment of nosocomial or concomitant bacterial pneumonia, prophylaxis against deep vein thrombosis and gastrointestinal bleeding and proper positioning of the patient to assist in oxygenation and ventilation, as shown in Table 2 below [2]. 
Table 2. Interventions to avoid patient complications [2].

\begin{tabular}{|c|c|}
\hline EARLY INTERVENTIONS & $M A N A G E M E N T$ \\
\hline $\begin{array}{l}\text { REDUCE DAYS OF INVASIVE MECHANICAL } \\
\text { VENTILATION }\end{array}$ & $\begin{array}{l}\text { USE WEANING PROTOCOLS THAT INCLUDE } \\
\text { DAILY ASSESSMENT OF SPONTANEOUS } \\
\text { RESPIRATORY CAPACITY. MINIMIZE THE } \\
\text { SEDATION, CONTINUOUS OR } \\
\text { INTERMITTENT, AIMING AT SPECIFIC } \\
\text { FINAL TITLATION POINTS OR WITH DAILY } \\
\text { INTERRUPTIONS OF CONTINUOUS } \\
\text { SEDATIVE INFUSIONS. }\end{array}$ \\
\hline $\begin{array}{l}\text { REDUCE THE INCIDENCE OF PNEUMONIA } \\
\text { ASSOCIATED WITH VENTILATION }\end{array}$ & $\begin{array}{l}\text { PREFER ORAL INTUBATION TO THE NASAL } \\
\text { AND PERFORM ORAL HYGIENE } \\
\text { REGULARLY. KEEP THE PATIENT IN A SEMI } \\
\text { RECLINED POSITION (HEAD RISE BETWEEN } \\
30^{\circ} \text { AND } 45^{\circ} \text { ). USE CLOSED SUCTION } \\
\text { SYSTEM; DRAIN PERIODICALLY AND } \\
\text { DISPOSE of THE CONDENSATE IN PIPE. USE } \\
\text { A NEW VENTILATION CIRCUIT FOR EACH } \\
\text { PATIENT; PERFORM THE EXCHANGE } \\
\text { WHENEVER IT IS DIRTY OR DAMAGED, BUT } \\
\text { NOT ROUTINE. REPLACE THE HUMIDIFIER } \\
\text { AS MALFUNCTIONS, DIRTinesS OR EVERY 5-7 } \\
\text { DAYS, FOLLOWING THE MANUFACTURER'S } \\
\text { RECOMMENDATIONS AND ACCORDING TO } \\
\text { THE PROTOCOLS DEFINED BY THE HEALTH } \\
\text { SERVICE CCIH. REDUCE THE INVASIVE } \\
\text { MECHANICAL VENTILATION TIME. }\end{array}$ \\
\hline REDUCE INCIDENCE OF VENOUS & USE PHARMACOLOGICAL PROPHYLAXIS IN \\
\hline THROMBOEMBOLISM & $\begin{array}{l}\text { PATIENTS WITHOUT CONTRAINDICATION. } \\
\text { IF CONTRAINDICATIONS ARE USED, USE } \\
\text { MECHANICAL PROPHYLAXIS. }\end{array}$ \\
\hline REDUCE INCIDENCE OF BLOOD INFECTION & ADOPT A SIMPLE CHECKLIST TO REMIND \\
\hline BY CATHETER & $\begin{array}{l}\text { THE DATE OF INSERTING THE CATHETER } \\
\text { AND REMOVING IT WHEN NO MORE } \\
\text { NEEDED. }\end{array}$ \\
\hline $\begin{array}{l}\text { MINIMIZE OCCURRENCE OF DECUBLE } \\
\text { ULCERS }\end{array}$ & $\begin{array}{l}\text { PROMOTE CHANGE OF DECUBBUS EVERY } \\
\text { TWO HOURS. }\end{array}$ \\
\hline
\end{tabular}

Source: World Health Organization, June 2020, adapted.

In this sense, data from China and Italy suggest that patients with hypoxemic COVID-19 respond well to PEEP, indicating a crucial role of NIV as a therapeutic and palliative measure to prevent intubation. Statistics from retrospective analyzes in China indicate that up to $30 \%$ of admitted patients required NIV, 84 while the first reports from Italy indicate values close to $31 \%$. Given current epidemiological trends, these requirements are likely to exceed the current capacity of most hospitals, if not all, if aggressive preparatory measures are not taken [23].

In this effort, it is important to characterize patients with COVID-19 who need treatment in an ICU. In this context, a retrospective study was carried out with 1,591 consecutive patients with COVID-19 confirmed in the laboratory and referred for admission to the ICU at the center of the Fondazione IRCCS coordinator 
Ca 'Granda Ospedale Maggiore Policlinico, Milan, Italy, of the 72 hospitals in this network among February 20 and March 18, 2020. The date of the final follow-up was March 25, 2020. Therefore, in this series of cases of critically ill patients with laboratory-confirmed COVID-19, admitted to ICUs in Lombardy, Italy, the majority were older men, a large proportion required mechanical ventilation and high levels of PEEP, and ICU mortality was $26 \%$ [24].

Another study looked at the relationship between obesity and SARS by SARS-CoV-2. In this retrospective cohort study, the relationship between clinical characteristics, including body mass index (BMI) and the need for invasive mechanical ventilation (IMV) in 124 consecutive patients admitted to intensive care by SARS-CoV-2, was analyzed, in a single French center. Obesity (BMI $>30 \mathrm{~kg} / \mathrm{m}^{2}$ ) and severe obesity (BMI> $35 \mathrm{~kg} / \mathrm{m}^{2}$ ) were present in $47.6 \%$ and $28.2 \%$ of cases, respectively. Overall, 85 patients (68.6\%) required IMV. The proportion of patients who needed IMV increased with the BMI categories $(\mathrm{p}<0.01$, chi-square test for trend), and was higher in patients with a BMI $>35 \mathrm{~kg} / \mathrm{m}^{2}(85.7 \%)$. In multivariate logistic regression, the need for IMV was significantly associated with male gender $(\mathrm{p}<0.05)$ and BMI $(\mathrm{p}<0.05)$, regardless of age, diabetes, and hypertension. The proportion ratio for IMV in patients with a BMI $>35 \mathrm{~kg} / \mathrm{m}^{2}$ versus patients with a BMI $<25 \mathrm{~kg} / \mathrm{m}^{2}$ was 7.36 . Therefore, there was a high frequency of obesity among patients admitted to intensive care with COVID-19. The severity of the disease worsened as the BMI increased. Thus, obesity is a risk factor for the severity of SARS-CoV-2, requiring greater attention to preventive measures in susceptible individuals [25].

Based on current data from China and Italy, it is recommended to expand the storage of NIV devices and ventilators in hospitals in general. To combat hospital spread and aerosolization of the SARS-CoV-2 virus, priority was given to double-limbed NIV devices with expiratory filters, such as the PB840 ventilator Viral filter proximal to the leak port on single-limb devices, single-member NIV devices use CPAP with viral filters before PEEP valves. It is strongly recommended to provide part of the emergency and inpatient units for patients with COVID-19, with patient bays and rooms equipped to administer NIV [26].

\section{CONCLUSION}

Through official documents of the Ministry of Health of Brazil, based on the regulations of the World Health Organization, it is recommended that hospitalized patients diagnosed with SARS and that the cases identified with the symptoms of severity have admitted to an intensive care bed. These symptoms are persistent hemodynamic instability (blood pressure that did not respond to volume replacement $(30 \mathrm{~mL} / \mathrm{kg}$ in the first 3 hours), indicating the use of vasoactive amine (example: norepinephrine, dopamine, adrenaline), signs and symptoms of respiratory failure, including hypoxemia ( $\mathrm{PaO} 2$ below $60 \mathrm{mmHg}$ ) requiring oxygen supplementation to maintain arterial oxygen saturation above $90 \%$, progressing to other organic disorders, such as acute renal failure and neurological dysfunction.

It was defined that the clinical criteria for hospital discharge should take into account the improvement of the clinical picture, the absence of tachydyspnea and hypoxia, the absence of $\mathrm{O} 2$ supplementation for at least 24 hours, the hemodynamic stability, the good acceptance of the oral route and the absence of fever. The reappearance of tachycardia, recurrence of fever, worsening of the general condition, or respiratory symptoms indicate the need for an immediate return of the child who has already has discharged from health services.

Prophylactic use of antibiotics was not recommended, but use should be considered based on the suspicion of associated bacterial infection. It is recommended that critically ill patients, without Covid-19 etiological confirmation, be managed according to the SARS protocol and that supportive treatment should focus on reversing hypoxemia. Mechanical ventilation indication should follow pediatric protective ventilation protocols in patients with SARS.

\section{Declaration of Potential Conflict of Interest}

The authors declare no conflict of interest.

\section{Funding}


Nothing declared

\section{REFERENCES}

1. World Health Organization. Report of the WHO-China joint mission on Coronavirus Disease 2019 (COVID-19). 2020.

2. World Health Organization. Advice on the use of masks the community, during home care and in health care settings in the context of the novel coronavirus (2019-nCoV) outbreak Interim guidance, 29 Jan. 2020. WHO/nCov/IPC_Masks/2020.1. Disponível em: https://www. who.int/emergencies/diseases/novel-coronavirus-2019/technical-guidance. Acesso em: mar. 2020.

3. World Health Organization. Clinical management of severe acute respiratory infection when novel coronavirus (2019-nCoV) infection is suspected: Interim guidance. Jan. 2020. Disponível em: https://www.who.int/publications-detail/clinical-management-of-severe-acute- respiratory-infectionwhen-novel-coronavirus-(ncov)-infection-is-suspected. Acesso em: mar. 2020.

4. World Health Organization. Clinical management of severe acute respiratory infection (SARI) when COVID-19 disease is suspected: Interim guidance. Mar. 2020. V. 1.2. Disponível em: https://www.who.int/publications-detail/clinical-management-of-severe-acute-respiratory- infectionwhen-novel-coronavirus-(ncov)-infection-is-suspected. Acesso em: mar. 2020.

5. World Health Organization. Novel Coronavirus (2019-nCoV) technical guidance. 2020. Disponível em: https://www.who.int/emergencies/diseases/novel-coronavirus-2019. Acesso em: mar. 2020.

6. Agência Nacional De Vigilância Sanitária (Brasil). Nota Técnica $\mathrm{n}^{0}$ 04/2020. Orientações para serviços de saúde: medidas de prevenção e controle que devem ser adotadas durante a assistência aos casos suspeitos ou confirmados de infecção pelo novo coronavírus (SARS-CoV-2). Atualizada em 31 mar. 2020. Disponível em: http://http://portal.anvisa.gov. br/documents/33852/271858/Nota+T\%C3\%A9cnica+n+04-2020+GVIMS-GGTES-ANVISA/ ab598660-3de4-4f14-8e6f-b9341c196b28. Acesso em: mar. 2020.

7. Associação De Medicina Intensiva Brasileira. Orientações sobre o manuseio do paciente com pneumonia e insuficiência respiratória devido a infecção pelo Coronavírus (SARS-CoV-2). Versão n. 3, 2020. Disponível em: https://www.amib.org.br/fileadmin/ user_upload/amib/2020/marco/29/Orientacoes_sobre_o_manuseio_do_paciente_com_ pneumonia_e_insuficiencia_respiratoria_devido_a_infeccao_pelo_Coronavirus_SARS-CoV-2_-- Versao_n.032020.pdf. Acesso em: mar. 2020.

8. Brasil. Ministério da Saúde. Secretaria de Ciência, Tecnologia e Insumos Estratégicos. Departamento do Complexo Industrial e Inovação em Saúde. Classificação de risco dos agentes biológicos. 3. ed. Brasília, DF: MS, 2017.

9. Brasil. Ministério da Saúde. Secretaria de Vigilância em Saúde. Boletim Epidemiológico, n. 1, Brasília, DF: Secretaria de Vigilância em Saúde SVS/MS-COE, Jan. 2020. Disponível em: http:// portalarquivos2.saude.gov.br/images/pdf/2020/janeiro/28/Boletim-epidemiologicoSVS-28jan20. pdf. Acesso em: mar. 2020.

10. Brasil. Ministério da Saúde. Secretaria de Vigilância em Saúde. Departamento de Vigilância das Doenças Transmissíveis. Protocolo de tratamento de Influenza: 2017. Brasília, DF: MS, 2018. Disponível em: http://bvsms.saude.gov.br/bvs/publicacoes/protocolo_tratamento_ influenza_2017.pdf. Acesso em: mar. 2020.

11. Centers For Disease Control And Prevention. Interim Infection Prevention and Control Recommendations for Patients with Known or Patients Under Investigation for 2019 Novel Coronavirus (2019-nCoV) in a Healthcare Setting, 2020. Disponível em: https://www.cdc. gov/coronavirus/2019ncov/hcp/infection-control.html. Acesso em: mar. 2020.

12. Guan, W. et al. Clinical Characteristics of Coronavirus Disease 2019 in China. New england Journal of Medicine, 2020. Disponível em: https://www.nejm.org/doi/pdf/10.1056/NEJMoa20020 32?articleTools=true. Acesso em: mar. 2020.

13. Huang, C. et al . Clinical features of patients infected with 2019 novel coronavirus in Wuhan, China. The Lancet, London, 2020. Disponível em: https://www.thelancet.com/action/showPdf?pi i=S01406736\%2820\%2930183-5. Acesso em: mar. 2020. 
14. Instituto Latino Americano De Sepse. Implementação de protocolo gerenciado de Sepse: Protocolo Clínico. 2018. Disponivel em: https://www.ilas.org.br/assets/arquivos/ ferramentas/protocolo-detratamento.pdf. Acesso em: mar. 2020.

15. Weiss, S. L. et al . Surviving sepsis campaign international guidelines for the management of septic shock and sepsis-associated organ dysfunction in children. Intensive Care Medicine, 2020. Dísponível em: https://doi.org/10.1007/s00134-019-05878-6. Acesso em: mar. 2020.

16. Wu Z, McGoogan JM. Characteristics of and Important Lessons From the Coronavirus Disease 2019 (COVID-19) Outbreak in China: Summary of a Report of72 314 Cases From the Chinese Center for Disease Control and Prevention. JAMA.

17. Tian S, Hu N, Lou J, Chen K, Kang X, Xiang Z, et al. Characteristics of COVID-19 infection in Beijing. Journal of Infection.

18. Wang D, Hu B, Hu C, Zhu F, Liu X, Zhang J, et al. Clinical Characteristics of 138 Hospitalized Patients With 2019 Novel Coronavirus-Infected Pneumonia in Wuhan, China. JAMA.

19. Zhang J-J, Dong X, Cao Y-Y, Yuan Y-D, Yang Y-B, Yan Y-Q, et al. Clinical characteristics of 140 patients infected with SARS-CoV-2 in Wuhan, China. European journal of allergy and clinical immunology.

20. Wu J, Liu J, Zhao X, Liu C, Wang W, Wang D, et al. Clinical Characteristics of Imported Cases of COVID-19 in Jiangsu Province: A Multicenter Descriptive Study. Clinical Infectious Diseases.

21. Yang X, Yu Y, Xu J, Shu H, Xia J, Liu H, et al. Clinical course and outcomes of critically ill patients with SARS-CoV-2 pneumonia in Wuhan, China: a single-centered, retrospective, observational study. The Lancet Respiratory Medicine.

22. Li K, Wu J, Wu F, Guo D, Chen L, Fang Z, et al. The Clinical and Chest CT Features Associated with Severe and Critical COVID-19 Pneumonia. Investigative Radiology.

23. Liu W, Wang F, Li G, Wei Y, Li X, He L, et al. Analysis of 2019-nCoV Infection and Clinical Manifestations of Outpatients: An Epidemiological Study from the Fever Clinic in Wuhan, China. Rochester, NY: Social Science Research Network. The Lancet

24. Grasselli G, Zangrillo A, Zanella A, et al. Baseline Characteristics and Outcomes of 1591 Patients Infected With SARS-CoV-2 Admitted to ICUs of the Lombardy Region, Italy [published online ahead of print, 2020 Apr 6]. JAMA . 2020;323(16):1574-1581. doi:10.1001/jama.2020.5394.

25. Simonnet A, Chetboun M, Poissy J, et al. High prevalence of obesity in severe acute respiratory syndrome coronavirus-2 (SARS-CoV-2) requiring invasive mechanical ventilation [published online ahead of print, 2020 Apr 9]. Obesity (Silver Spring) . 2020;10.1002/oby.22831. doi:10.1002/oby.22831.

26. Giwa AL, Desai A, Duca A. Novel 2019 coronavirus SARS-CoV-2 (COVID-19): An updated overview for emergency clinicians. Emerg Med Pract . 2020;22(5):1-28. 